\title{
Assessment of potential ecological risk index based on heavy metal elements for organic farming in micro catchments under humid ecological condition
}

\author{
Nalan Kars a, Orhan Dengiz ${ }^{b, *}$
}

a Republic of Turkey Ministry of Agriculture and Forestry Black Sea Agricultural Research Institute, Samsun, Turkey b Ondokuz Mayıs University, Faculty ofAgriculture, Department of Soil Science and Plant Nutrition, Samsun, Turkey

\section{Article Info}

Received : 11.10 .2019

Accepted : 10.04.2020

\begin{abstract}
Soil pollution, influenced by both the natural and anthropogenic factors, significantly reduces environmental quality. This research was carried out in some micro catchments located on Ordu province of Black Sea Region-Turkey in order to determine potential ecological risk index based on heavy metal elements (HMs) for organic farming. For this purpose, 166 soil samples $(0-20 \mathrm{~cm})$ were taken from the study area and some physical and chemical and HM concentrations $(\mathrm{Cd}, \mathrm{Cu}, \mathrm{Cr}, \mathrm{Ni}, \mathrm{Pb}$ and $\mathrm{Zn}$ ) analysis were done. In this study, it was determined; i-) some physical and chemical properties of catchments' soils, ii-) HM contents and the correlation relation between physico-chemical properties of soil and HM concentrations and iii-) potential ecological risk index (PERI). PERI was calculated using the data obtained to evaluate the environmental risks of HMs in the region. The results showed that $\mathrm{Cu}$ concentration in $3 \%, \mathrm{Cr}$ in $0.6 \%$ and $\mathrm{Ni}$ in $4.8 \%$ of the soil samples exceeded the threshold levels whereas, the concentrations of other HMs were lower than the critical values. Statistically, it was also found significantly positive relationships between sand content and $\mathrm{Cu}$ of soils whereas, it was determined significantly negative relationships between EC and $\mathrm{Cu}$. In addition, according to the obtained PERI results, while $54 \%$ of total soil samples were low while, $42 \%$ of them were moderate class. Only $4 \%$ of them were classified as significant ecological risk level. Moreover, according to mean potential ecological risk index of these HMs, it can be ordered as $\mathrm{Cd}>\mathrm{Pb}>\mathrm{Cu}>\mathrm{Ni}>\mathrm{Zn}>\mathrm{Cr}$.
\end{abstract}

Keywords: Heavy metal, potential ecological risk, micro catchment, humid ecological condition, Black Sea Region.

(C) 2020 Federation of Eurasian Soil Science Societies. All rights reserved

\section{Introduction}

Nowadays, contamination of heavy metal elements has become an environmental issue in both developed and developing countries throughout the World (Tam and Wong, 2000; Sun et al., 2010). Natural toxicities of heavy metals, having a large number of sources, not being biodegraded and being able to survive for a long time; It has increased the importance of ecological and environmental studies on metal accumulation (Gao et al., 2016). Rapid urbanization, industrialization, agricultural practices and the use of fossil fuels are the main causes of heavy metal accumulation in soil, especially in water resources, street dust, sediment, aquatic organisms consumed by humans and in the food chain (El Nemr, 2011; Chaudhari et al., 2012; Yang et al., 2014; Cheng et al., 2015). Under certain environmental conditions, heavy metals might accumulate up to toxic concentration levels, and cause ecological damage (Bai et al., 2011; El Nemr et al., 2012).

An important problem is how to assess heavy metal deposits and how to distinguish man-made contribution from natural concentrations (Bing et al., 2013). Many indexes have been developed to evaluate the accumulation of heavy metals and the environmental problems they create. For example, in order to

\begin{tabular}{llll}
\hline Nalan Kars & $:$ & nalankars@hotmail.com \\
Orhan Dengiz & $:$ & odengiz@omu.edu.tr \\
\hline
\end{tabular}


determine the accumulations of anthropogenic origin and to identify possible ecological risks; Enrichment factor, contamination factor, geo-accumulation index, potential ecological risk index are frequently used indices (Rashed, 2010; Yang et al., 2011; Bing et al., 2013; Islam et al., 2015; Kükrer et al., 2015).

Structural and textural properties of the soil, cation exchange capacity (CEC), $\mathrm{pH}$ and amount of organic matter have an effective role in the retention of heavy metals in the soil. Especially due to the high CEC of clay, soils hold heavy metals more than other soils with higher clay and organic matter content hold difficult metals and form strong soluble compounds. Variation of these elements or compounds deposited in the soil along the soil profile, it depends on the characteristics of the soils and the intensity of agricultural activities, and the distribution of metals in the soil profile is indicative of air pollution, soil genesis and anthropogenic pollution (Wilcke et al., 2000; Cemek and Kizilkaya, 2006).

The objectives of this present study was (i) to determine some physico-chemical soil properties of some micro catchment in Ordu province, (ii) to determine the correlation between heavy metal (HM) contents and physico-chemical properties of soil, (iii) to assess the environmental risks of heavy metals in the micro catchments.

\section{Material and Methods}

\section{Study area}

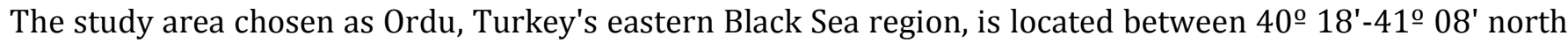
parallel 360 52'-38 $12^{\prime}$ eastern meridians (Figure 1). Ordu is surrounded by the Black Sea from the north, Giresun from the east, Sivas and Tokat from the south, and Samsun from the west. The total area of Ordu is approximately $6141 \mathrm{~km}^{2}$. About $10.2 \%$ of the province consists of meadow and pasture areas, while about $28.7 \%$ of it has forest areas. In addition, the area where have been used agricultural activities are carried out covers approximately $52.0 \%$ (DOKAP, 2018).

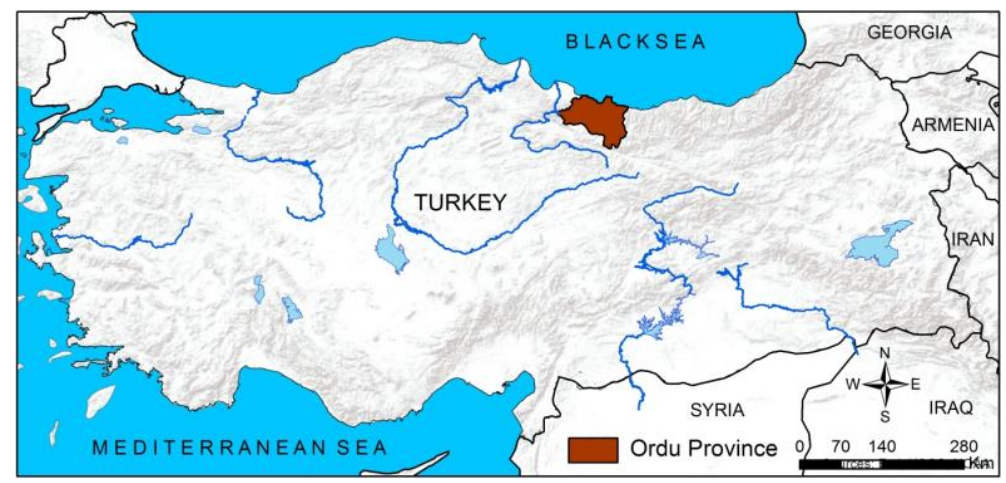

Figure 1. Location map of the study area

Ordu has a typical Black Sea climate which means that winters are mild and cool summers and shows humid ecological conditions. According to long-term climate data (1959-2018) the average annual rainfall and annual average temperature are $1038.4 \mathrm{~mm}, 14.4^{\circ} \mathrm{C}$, respectively (TMS, 2015). An insight into climatic conditions of the Black Sea Region can be found in the study (Mihálikova et al., 2016). These steep slopes play an important role in growing hazelnut and tea. The study area is located at an altitude of $0-3082 \mathrm{~m}$ above sea level. In the majority of the northern part of the region has a mountainous and rugged topography with steep and very steep slopes (>50\% slope) (Figure 2).
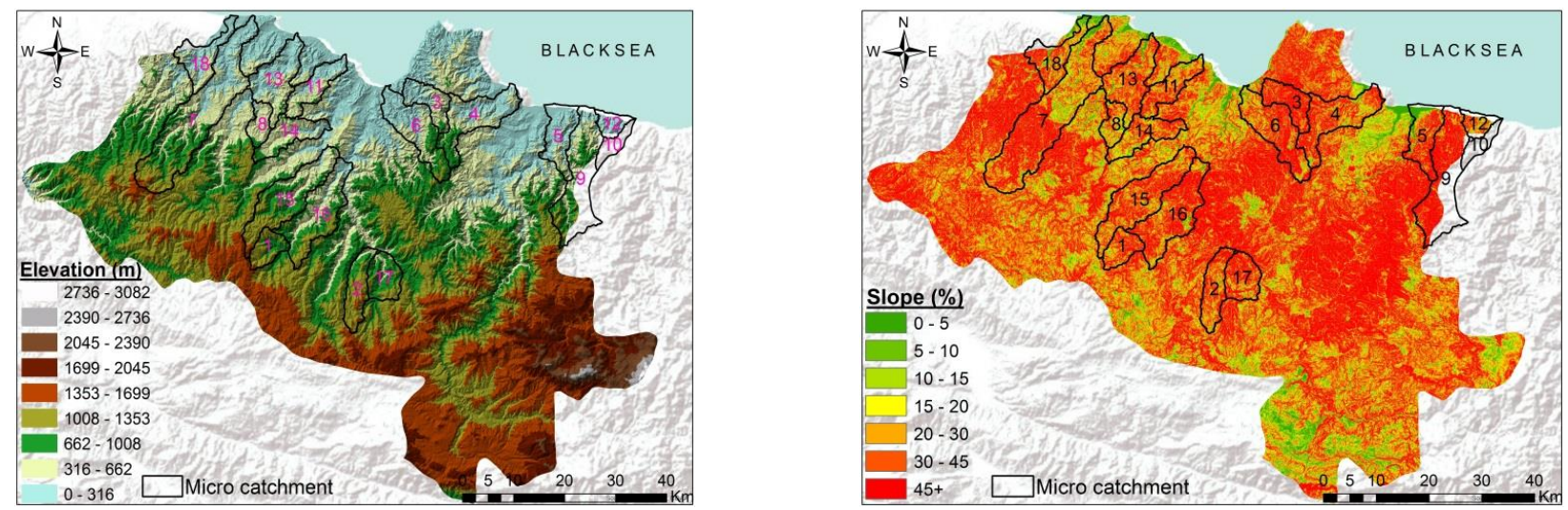

Figure 2. Elevation and slope maps of the Ordu Province 


\section{Soil Sampling and analysis}

Field study was conducted in 2017. Soil samples which were classified as gray brown podzolic, brown forest, Non-calcerious brown forest, redish yellow podzolic, alluvial, high mountain meadow and colluvial great soil group according to old American soil classification system (GDRS, 1984) were taken from 166 soil in total agricultural lands (Figure 3). Sampling was carried out after autumn harvest and before the crop growing season. In addition, the coordinates were recorded using global positioning system (GPS) device.

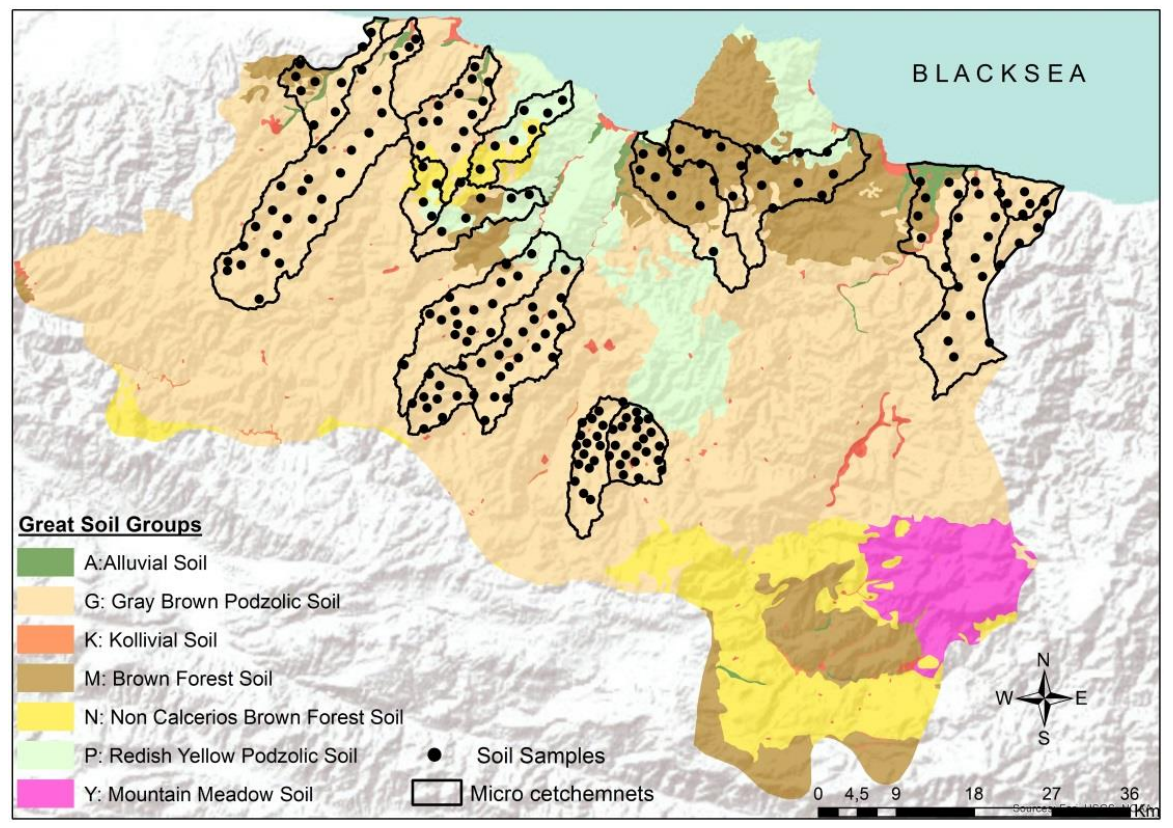

Figure 3. Soil samples pattern in great soil group map of the study area

Soil samples taken from the field were air dried and sieved from a screen with $2 \mathrm{~mm}$ opening size to prepare for analysis. Sand, silt, clay contents of the soil samples were determined by Hydrometer method (Bouyoucos, 1962). Soil pH values were measured in soil suspension (1:1, w:v) by glass electrode $\mathrm{pH}$ meter and EC values were determined in the same soil suspension (1:1, w:v) by EC meter (Rowell, 1996). Soil organic matter (OM) contents were determined by modified Walkley-Black method (Walkley and Black, 1934). Lime $\left(\mathrm{CaCO}_{3}\right)$ contents of soils were determined by Scheibler calcimeter (Nelson, 1982). Total heavy metal (Cu, Cd, Cr, Pb, Ni, Zn) contents were determined by EPA 3051 using ICP-OES (Kloke, 1980)

Potential ecological risk assessment of heavy metals referred to Hakanson (1980) method with the following formula:

$$
\begin{array}{r}
C F=\frac{C_{s}^{i}}{C_{r}^{i}} \\
\text { PER }=\mathrm{TRF} \times \mathrm{CF} \\
\text { PERI }=\sum \text { PER }
\end{array}
$$

Where; $\mathrm{C}_{-} \mathrm{s}^{\wedge} \mathrm{i}$ : is the measured concentration of heavy metal in each soil sample; $\mathrm{C}_{-} \mathrm{r}^{\wedge} \mathrm{i}$ : is reference value, here the background value of each heavy metal in soil is used (Taylor, 1964; Hasan et al., 2013) , CF is the pollution of a single element factor (contamination factor); PER is the potential ecological risk index of a single element; PERI is a comprehensive potential ecological risk index; and TRF is the toxic response factor of a single element (Kloke, 1980), which is determined for $\mathrm{Zn}=1, \mathrm{Cr}=2, \mathrm{Cu}=\mathrm{Pb}=\mathrm{Ni}=5$ and $\mathrm{Cd}=30$. The terminology used to describe the risk PERI was suggested by (Kloke, 1980; Long et al., 1995), where: PERI < 95 indicates a low potential ecological risk; $95<$ PERI $<190$ is a moderate ecological risk; $190<$ PERI $<380$ is a considerable ecological risk and PERI $>380$ is a very high ecological risk.

\section{Results and Discussion}

\section{Soil physical and chemical properties and heavy metals}

Some researchers indicated that some chemical such as $\mathrm{pH}, \mathrm{CEC}$, organic matter contents and physical such as clay content are the essential soil characteristics that designate the capacity to hold heavy metal pollutants (Omran, 2016; Gabrielyan et al., 2018). The descriptive statistical parameters (mean, maximum, minimum, and coefficients of variation) of the some physical, chemical properties and heavy metals related to 166 soil samples taken from surface $(0-20 \mathrm{~cm})$ of the crop lands in 18 micro catchments of the Ordu province were presented in Table 1. The average clay content of the micro catchments' soils was $23.31 \%$, 
and $55 \%$ are slightly coarse soils. The $\mathrm{pH}$ values of soil samples varied between $68 \%$ strong-medium-light acid, while soil samples; It has $99 \%$ salt-free, $88 \%$ lime-free, $38 \%$ medium and $32 \%$ high organic matter content. When the heavy metal contents in the research area are examined, it is seen that $\mathrm{Cu}, \mathrm{Cr}$ and $\mathrm{Ni}$ elements are above the limit values in the surface soil in some micro catchments (Table 1). The statistics results showed that the mean value of soil $\mathrm{Cu}, \mathrm{Cd}, \mathrm{Cr}, \mathrm{Pb}, \mathrm{Ni}$ and $\mathrm{Zn}$ concentrations was 39.99, 0.54, 15.36, 11.83, 14.86 and $30.46 \mathrm{mg} \mathrm{kg}^{-1}$, respectively. Especially $\mathrm{Ni}$ and $\mathrm{Cu}$ were determined in micro catchments coded as 7 in Akkuş and Çaybaşı district boundaries and micro catchments coded as 2 and as 17 in Aybastı, Gölköy and Kabataş district boundaries. Grouping of heavy metal concentrations was detected in all catchments except the southern parts of the Çarşıbaşı district. Although not dense, $\mathrm{Cu}, \mathrm{Cr}$ and $\mathrm{Ni}$ may be caused by the increase in solubility of soils due to acidification process, and $\mathrm{Cu}$ may be caused by pesticides containing copper element in the active substance especially in areas where intensive hazelnut cultivation is carried out. There was high variations and great skewness for $\mathrm{Cr}$ (117.26\% and 4.76). Coefficients of variation $(\mathrm{CV}) \%$ values show the mean variation of each sampling site in the population. In this current study, it was found that the order of the $\mathrm{CV} \%$ for heavy metal element from high to low was $\mathrm{Cr}>\mathrm{Ni}>\mathrm{Pb}>$ $\mathrm{Cd}>\mathrm{Cu}>\mathrm{Zn}$. In some researches, it has been shown that high $\mathrm{Ni}$ level is caused by parent material and $\mathrm{Pb}$ content is caused by particle from surrounding lead acid battery factory (Pesantes et al., 2019). In addition, mean value of PERI was found 90.91 which indicate as low potential ecological risk in general for all soil samples. However, it should be evaluated each soil samples taken from each individual micro catchment.

Table 1. Descriptive statistical analysis of physical and chemical properties and heavy metal of soil samples

\begin{tabular}{|c|c|c|c|c|c|c|c|}
\hline Parameters & Min. & Max. & Mean & SD & $\mathrm{CV}, \%$ & Skewness & Kurtosis \\
\hline \multicolumn{8}{|c|}{ Physical and chemical properties } \\
\hline Sand, $\%$ & 22.31 & 84.62 & 51.11 & 12.84 & 25.12 & 0.01 & -0.47 \\
\hline Clay, \% & 5.57 & 56.02 & 23.58 & 10.74 & 45.54 & 0.55 & -0.31 \\
\hline Silt, \% & 2.35 & 40.86 & 25.31 & 5.50 & 21.73 & -0.41 & 1.73 \\
\hline $\mathrm{pH}, 1: 2.5$ & 4.24 & 8.10 & 6.02 & 0.92 & 15.28 & 0.25 & -0.98 \\
\hline $\mathrm{EC}, \mathrm{dS} \mathrm{m}^{-1}$ & 0.06 & 1.22 & 0.33 & 0.21 & 63.63 & 1.15 & 1.54 \\
\hline $\mathrm{CaCO}_{3}, \%$ & 0.00 & 39.25 & 1.50 & 5.48 & 365.33 & 4.72 & 23.38 \\
\hline $\mathrm{OM}, \%$ & 0.31 & 5.99 & 2.98 & 1.44 & 48.32 & 0.43 & -0.87 \\
\hline \multicolumn{8}{|c|}{ Heavy metals } \\
\hline $\mathrm{Cu}(0-100)^{\#}$ & 8.19 & 164.26 & 39.99 & 24.47 & 61.19 & 1.73 & 4.46 \\
\hline $\mathrm{Cd}(0-3) \#$ & 0.00 & 2.42 & 0.54 & 0.39 & 71.46 & 1.46 & 4.67 \\
\hline $\operatorname{Cr}(0-100)^{\#}$ & 1.20 & 166.04 & 15.36 & 18.01 & 117.26 & 4.76 & 31.87 \\
\hline $\mathrm{Pb}(0-100)^{\#}$ & 2.20 & 96.24 & 11.83 & 8.85 & 74.78 & 6.34 & 53.78 \\
\hline $\mathrm{Ni}(0-50)^{\#}$ & 3.54 & 120.13 & 14.86 & 14.76 & 99.33 & 4.10 & 20.88 \\
\hline $\operatorname{Zn}(0-300)^{\#}$ & 10.52 & 91.23 & 30.46 & 12.77 & 41.91 & 1.65 & 3.90 \\
\hline PERI & 6.80 & 373.66 & 90.91 & 2.89 & 3.18 & 1.50 & 4.71 \\
\hline
\end{tabular}

SD: Standard deviation, Min.: Minimum, Max.: Maximum, n: sample number, EC: Electric conductivity, OM: Organic matter. EC: Electrical conductivity, pH: soil reaction, ${ }^{*} \mathrm{CV}$ (Coefficient of Variation), **skewness: $<|\mp 0.5|=$ Normal distribution, $0.5-1.0=$ Application of character changing for dataset, and > $1.0 \rightarrow$ application of Logarithmic change, \#: Maximum permissible concentration (mg kg-1)

\section{Correlation Analysis}

Correlation analysis of some physical and chemical properties and heavy metal content of micro-catchment soils were performed (Table 2). Heavy metals have a significantly relationships organic content, clay and fine silt particles because of their high CEC (Tjahjono and Suwarno, 2018). A positive correlation was determined between sand content and $\mathrm{Cu}(\mathrm{p}<0.01)$ and $\mathrm{Zn}(\mathrm{p}<0.01)$ whereas, a negative correlation was detected between clay content and $\mathrm{Cu}(\mathrm{p}<0.01)$ and $\mathrm{Zn}(\mathrm{p}<0.01)$. In addition, there was a negative relationship between the EC value and $\mathrm{Cu}$ content of the soils whereas, a positive correlation between lime value and $\mathrm{Cd}$ content as well as a positive relationship between $\mathrm{OM}$ value and $\mathrm{Cd}$ content. Moreover, it was found that a significant negative correlation was found between the total copper content and the Cd concentrations, whereas a positive correlation was determined between the $\mathrm{Cu}$ content and $\mathrm{Cr}(\mathrm{p}<0.01)$ and $\mathrm{Zn}(\mathrm{p}<0.01)$ contents. There was a positive correlation between $\mathrm{Cd}$ content and $\mathrm{Pb}(\mathrm{p}<0.01)$ content and a negative correlation with $\mathrm{Cr}$ content $(\mathrm{p}<0.01)$. In addition, positive relationships were found between both $\mathrm{Cr}$ content and $\mathrm{Ni}(\mathrm{p}<0.01)$ concentration and between $\mathrm{Pb}$ content and $\mathrm{Zn}(\mathrm{p}<0.01)$ concentration. Many researchers have obtained similar results in correlation analysis between $\mathrm{OM}, \mathrm{pH}$, lime and soil particle distribution with heavy metal content of soils (Demir et al., 2016; Özyazıcı et al, 2017; Tang et al., 2018). On the other hand, some researchers (Tume et al., 2006; Nizami and Rehman, 2018) reported that there was no relationship between $\mathrm{pH}$ and $\mathrm{OM}$ content of soils and heavy metal contents. Potential ecological risk index was calculated and evaluated both separately for each metal and to reveal the total potential impact of all metals. 


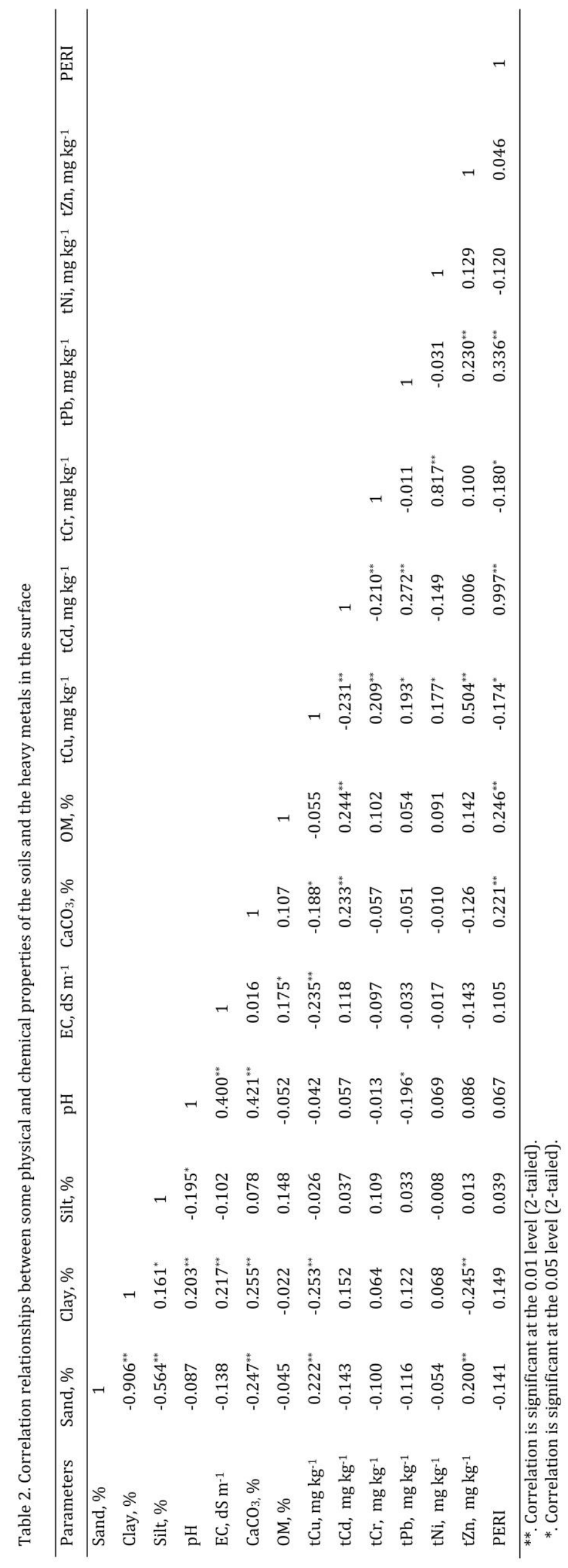




\section{Assessment of PERI for soil samples}

Among investigated heavy metals $(\mathrm{Cu}, \mathrm{Cd}, \mathrm{Cr}, \mathrm{Pb}, \mathrm{Ni}$ and $\mathrm{Zn}$ ), only cadmium and lead significantly correlated with the PERI (Table 2). According to researcher, this case shows that the possibility of both heavy metals in the micro catchments located inducing ecological risks was quite high (Effendi et al., 2016). Distribution map of soil samples for PERI classes was given in Figure 4. It was not detected high PERI classes in the micro catchments of Ordu province. In addition, PERI results, it was detected that while $54 \%$ of total soil samples were low while, $42 \%$ of them were moderate class. According to the potential ecological risk index results, $54 \%$ of the catchment soils was low; $42 \%$ was moderate; $4 \%$ was at significant ecological risk level. Moreover, it can be seen that almost all micro catchments have moderate classes whereas some micro catchments coded 11,13,16, 6 and 12 have considerable class. On the other hand, two micro catchments coded 3 and 4 have no potential ecological risk.

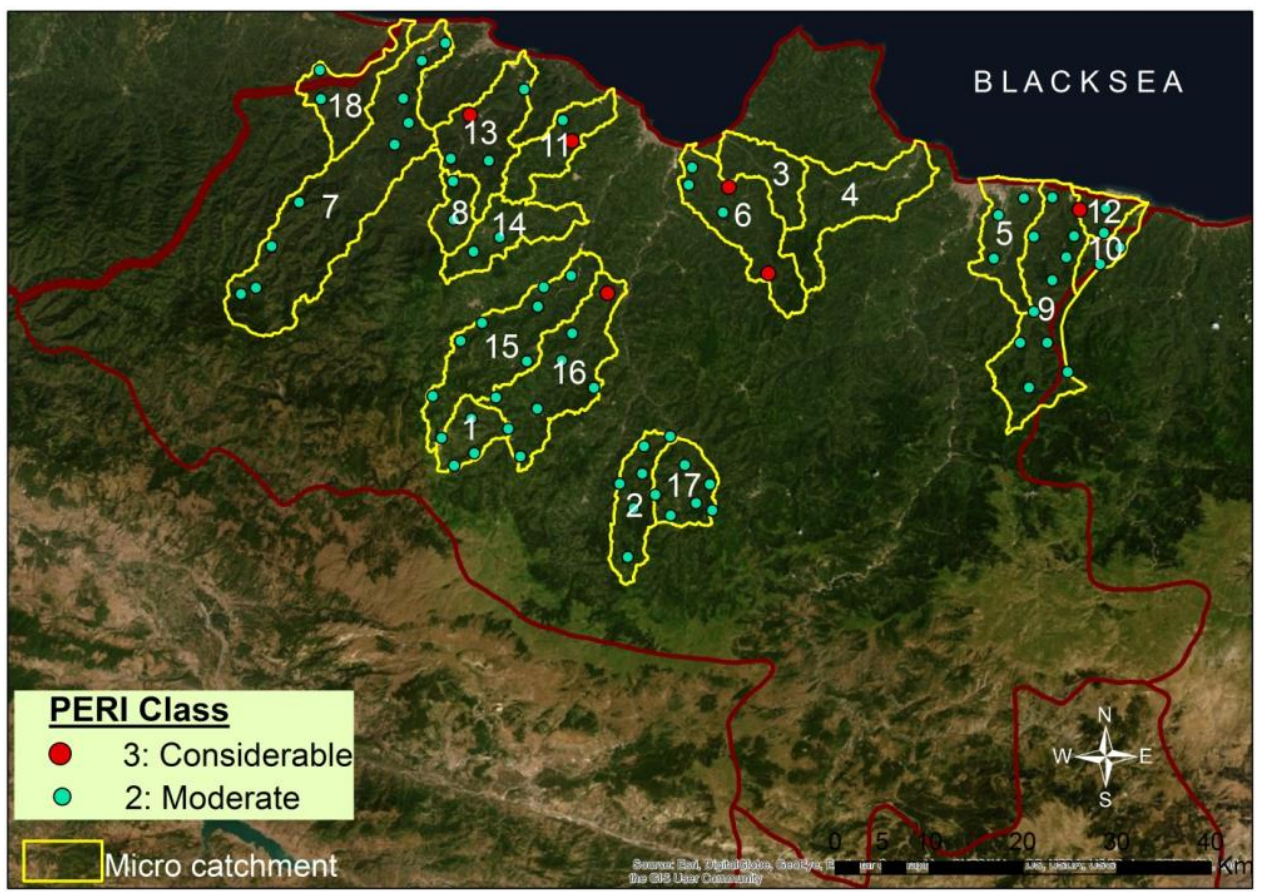

Figure 4. Distribution map of soil samples for PERI classes

In this present study, the greatest contribution to PERI comes from the Cd element. Accordingly, the ranking of heavy metals according to calculated average potential ecological risk indexes is $\mathrm{Cd}>\mathrm{Pb}>\mathrm{Cu}>\mathrm{Ni}>\mathrm{Zn}>\mathrm{Cr}$. In a study conducted by Islam et al (2015), considering the seriousness of potential ecological risks for single metal (PER), the decreasing order of pollutants $\mathrm{Cd}>\mathrm{As}>\mathrm{Cu}>\mathrm{Pb}>\mathrm{Ni}>\mathrm{Cr}$. Given the potential ecological risk (PERI), it has shown that all land soils are important for a very high potential ecological risk.

\section{Conclusion}

In addition to fossil fuels, chemical fertilizers, pesticides, fungicides and similar pesticide residues used in industrial applications and agricultural activities are pollutants that result from human activity. Heavy metals contaminated and accumulated in soils can cause many environmental, plant and human health problems, such as microbial activity, soil fertility, biodiversity and yield losses, and food chain poisoning. In this present study, heavy metal element contents for organic agriculture and their potential ecological risks were determined in some micro catchment soils of Ordu province. According to the Potential Ecological Risk Index (PERI), cadmium is the highest risk posing the toxic metals, whereas the other elements have low risk.

DAP, TSP and compound fertilizers consumed in agricultural soils to increase the yield, especially the $\mathrm{Cd}$ content is quite high and affect the many metabolic activities such as photosynthesis, respiration, ion uptake, growth and development by passing into the plant structure. That's why; the fact that $\mathrm{Cd}$, which has the highest ecological risk value, is not associated with other elements suggests that it reaches the ecosystem in different ways. The anthropogenic and geogenic elements were considered for the enrichment of metals in soil. The average of ecological risk potential was classified as moderate and low risk in this current study. Moreover, the soil $\mathrm{pH}$ decreases with the use of acidic fertilizers and causes the activity of heavy metals to increase. We all have various responsibilities for the protection of our land and water resources. Nowadays, it is seen that there is not enough precautions for soil pollution which is a universal problem in our country and there is not enough studies about polluted soils. Therefore, chemical fertilizers should be applied with a fertilization program based on analysis results under expert control. 


\section{References}

Amira, W., Leghouchi, E., 2018. Assessment of heavy metal pollution in sediments and their bioaccumulation in phragmites australis frome Nil river (Jijel- Algeria). Global NEST Journal 20(2): 226-233.

Bai, J., Xiao, R., Cui, B., Zhang, K., Wang, Q., Liu, X., Gao, H., Huang, L., 2011. Assessment of heavy metal pollution in wetland soils from the young and old reclaimed regions in the Pearl River Estuary, South China. Environmental Pollution 159(3): 817-824.

Baniamam, M., Moradi, A.M., Bakhtiari, A.R., Fatemi, M., Khanghah, K., 2019. Distribution and pollution level of nickel and vanadium in sediments from south part of the Caspian Sea, Iran. Indian Journal of Geo Marine Sciences 48(5): 765-771.

Bat, L., Arıcı, E., Öztekin, A., 2019. Heavy metals health risk appraisal in benthic fish species of the Black Sea. Indian Journal of Geo Marine Sciences 48(1): 163-168.

Bayrakl, B., Dengiz, O., 2019. Determination of heavy metal risk and their enrichment factor in intensive cultivated soils of Tokat Province. Eurasian Journal of Soil Science 8(3): 249-256.

Bing, H., Wu, Y., Liu, E., Yang, X., 2013. Assessment of heavy metal enrichment and its human impact in lacustrine sediments from four lakes in the mid-low reaches of the Yangtze River, China. Journal of Environmental Sciences 25(7): 1300-1309.

Bouyoucos, G.J., 1962. Hydrometer method improved for making particle size analysis of soils. Agronomy Journal 54(5): 464-465.

Cemek, B., Kızılkaya, R., 2006. Spatial variability and monitoring of Pb contamination of farming soils affected by industry. Environmental Monitoring and Assessment 117(1-3): 357-375.

Chaudhari, P.R., Gupta, R., Gajghate, D.G., Wate, S.R., 2012. Heavy metal pollution of ambient air in Nagpur City. Environmental Monitoring and Assessment 184: 2487-2496.

Cheng, H., Li, M., Zhao, C., Yang, K., Li, K., Peng, M., Yang, Z., Liu, F., Liu, Y., Bai, R., Cui, Y., Huang, Z., Li, L., Liao, Q., Luo, J., Jia, S., Pang, X., Yang, J., Yin, G., 2015. Concentrations of toxic metals and ecological risk assessment for sediments of major freshwater lakes in China. Journal of Geochemical Exploration 157: 15-26.

Decena, S.C.P., Arguellas, M.S., Robel, L.L., 2018. Assessing heavy metal contamination in surface sediments in an urban river in the Philippines. Polish Journal of Environmental Study 27(5): 1983-1995.

Demir, Y., Canbolat, M.Y., Demir, A.D., 2016. Assessment of some heavy metals of change that processed and unprocessed in lands throughout soil profile. Yüzüncü Yıl Üniversitesi Tarım Bilimleri Dergisi 26(4): 614-620 [in Turkish].

DOKAP., 2018. DOKAP Bölgesi organik tarım havzalarının belirlenmesi. organik tarım havzalarının haritalanması ve toprak analiz raporu. T.C. Sanayi ve Teknoloji Bak. Doğu Karadeniz Projesi Bölge Kalkınma İdaresi Başkanlığı, 288p. [in Turkish]. Available at [Access date: 11,10,2019]: https://www.dokap.gov.tr/Upload/Genel/dokaprapor-haritalandirma-toprak-analizi-14122018-pdfpdf-966323-rd_53.pdf

Effendi, H., Kawaroe, M., Lestaria, D.F., 2016. Ecological risk assessment of heavy metal pollution in surface sediment of Mahakam Delta, East Kalimantan. Procedia Environmental Sciences 33: 574-582.

El Nemr, A., 2011. Impact, monitoring and management of environmental pollution. Nova Science Publishers incorporated, New York, $638 \mathrm{p}$.

El Nemr, A., Khaled, A., Moneer A.A., El Sikaily, A., 2012. Risk probability due to heavy metals in bivalve from Egyptian Mediterranean coast. The Egyptian Journal of Aquatic Research 38(2): 67-75.

Gabrielyan, A.V., Shahnazaryan, G.Z., Minasyan, S.H.2018. Distribution and identification of sources of heavy metals in the Voghji River Basin Impacted by Mining Activities. Journal of Chemistry Article ID 7172426.

Gao, W., Du, Y., Gao, S., Ingels, J., Wang, D., 2016. Heavy metal accumulation reflecting natural sedimentary processes and anthropogenic activities in two contrasting coastal wetland ecosystems, eastern China. Journal of Soils and Sediments 16(3): 1093-1108.

GDRS., 1984. General Directory of Rural Service. Land Resource Inventory for Ordu. Ankara, Turkey. [in Turkish].

Hakanson, L., 1980. An ecological risk index aquatic pollution control. A sedimentological approach. Water Research 14(8): 975-1001.

Hasan, A.B., Kabir, S., Reza, A.H.M.S., Zaman, M.N., Ahsan, A., Rashid, M., 2013. Enrichment factor and geo-accumulation index of trace metals in sediments of the ship breaking area of Sitakund Upazilla (Bhatiary-Kumira), Chittagong, Bangladesh. Journal of Geochemical Exploration 125: 130-137.

Islam, M.S., Ahmed M.K., Al-Mamun, H.A., Masunag, A. S., 2015. Potential ecological risk of hazardous elements in different land-use urban soils of Bangladesh. Science of the Total Environment 512-513: 94-102.

Kloke, A., 1980. Orientierungsdaten fur tolerierbare gesa mtgehalte einiger elemente in kulturboden. Mitteilungen VDLUFA 1(3): 9-11.

Kükrer, S., Erginal, AE., Şeker, S., Karabıyıkoğlu, M., 2015. Distribution and environmental risk evaluation of heavy metal in core sediments from Lake Çıldır. Environmental Monitoring and Assessment 187: 453-462.

Long, E.R, MacDonald, D.D, Smith, S.C., Calder, F.D., 1995. Incidence of adverse biological effects within ranges of chemical concentration in marine and estuarine sediments. Environmental Management 19(1): 81- 97.

Mihálikova, M., Özyazıcı, M.A., Dengiz, O., 2016. Mapping soil water retention on agricultural lands in central and eastern parts of the Black Sea Region in Turkey. Journal of Irrigation and Drainage Engineering 142(12): 05016008-1. 
Nelson, R.E., 1982. Carbonate and gypsum. In: Methods of Soil Analysis, Part 2, Chemical and microbiological properties, Second Edition. Number 9, Page, A.L., Keeney, D. R., Baker, D.E., Miller, R.H., Ellis, R. Jr., Rhoades, J.D. (Eds.). ASASSSA, Madison, Wisconsin, USA. pp. 181-198.

Nizami, G., Rehman, S., 2018. Assessment of heavy metals and their effects on quality of water of rivers of Uttar Pradesh, India: A review. Journal of Environmental Chemistry and Toxicology 2(2): 65- 71.

Omran, E.E., 2016. Environmental modelling of heavy metals using pollution indices and multivariate techniques in the soils of Bahr El Baqar, Egypt. Modeling Earth Systems and Environment 2: 119.

Özyazıcı, M.A., Dengiz, O., Özyazıcı, G., 2017. Spatial distribution of heavy metals density in cultivated soils of Central and East Parts of Black Sea Region in Turkey. Eurasian Journal of Soil Science 6 (3): 197 - 205.

Pesantes, A.A., Carpio, E.P., Vitvar, T., López, M.M.M., Menéndez-Aguado, J.M., 2019. A multi-ındex analysis approach to heavy metal pollution assessment in river sediments in the Ponce Enríquez Area, Ecuador. Water 11: $590-602$.

Rashed, M.N., 2010. Monitoring of contaminated toxic and heavy metals, from mine tailings through age accumulation, in soil and some wild plants at Southeast Egypt. Journal of Hazardous Materials 178(1-3): 739-746.

Rowell, D.L., 1996. Soil science: Methods and applications. Longman Scientific \& Technical, Longman Group UK Ltd, Harlow, Essex, UK. 350 p.

Sun, Y.B., Zhou, Q.X., Xie, X.K., Liu, R., 2010. Spatial, sources and risk assessment of heavy metal contamination of urban soils in typical regions of Shenyang, China. Journal of Hazardous Materials 174(1-3): 455-462.

Tam, N.F.Y., Wong, Y.S., 2000. Spatial variation of Heavy metals in surface sediments of Hong Kong mangrove swamps. Journal of Environmental Pollution 110(2): 195-205.

Tang, J., Chai, L., Li, H., Yang, Z., Yang, W., 2018. A 10 -year statistical analysis of heavy metals in river and sediment in Hengyang Segment, Xiangjiang River Basin, China. Sustainability 10(4): 2-28.

Taylor, S.R., 1964. Abundance of chemical elements in the continental crust: a new table. Geochimica et Cosmochimica Acta 28(8): 1273-1285.

Tjahjono, A., Suwarno, D., 2018. The spatial distribution of heavy metal lead and cadmium pollution and coliform abundance of waters and surface sediment in Demak. Journal of Ecological Engineering 19(4): 43-54.

TMS., 2015. Turkish Meteorological Service. [in Turkish]. Available at [Access date: 11,10,2019]: https://www.mgm.gov.tr/veridegerlendirme/il-ve-ilceler-istatistik.aspx?m=0RDU

Tume, P., Bech, J., Longan, L., Tume, L., Reverter, F., Sepulveda, B., 2006. Trace elements in natural surface soils in Sant Climent (Catalonia, Spain). Ecological Engineering 27(2): 145-152.

Walkley, A.J., Black, I.A., 1934. Estimation of soil organic carbon by the chromic acid titration method. Soil Science 37(1): 29-38.

Wilcke, W., Kretzschmar, S., Bundt, M., Saborío, G., Zech, W. 2000. Depth distribution of aluminum and heavy metals in soils of Costa Rican coffee cultivation areas. Journal of Plant Nutrition and Soil Science 163(5): 499-502.

Yang, J., Chen, L., Liu, L.Z., Shi, W.L., Meng, X.Z., 2014. Comprehensive risk assessment of heavy metals in lake sediment from public parks in Shanghai. Ecotoxicology and Environmental Safety 102: 129-135.

Yang, Z.P., Lu, W.X., Long, Y.Q., Bao, X.H., Yang, Q.C., 2011. Assessment of heavy metals contamination in urban topsoil from Changchun City, China. Journal of Geochemical Exploration 108(1): 27-38. 